\title{
Pleistocene-Holocene sedimentation of Solimões-Amazon fluvial system between the tributaries Negro and Madeira, Central Amazon
}

\author{
Sedimentação Pleistocênica-Holocênica do sistema fluvial Solimões- \\ Amazonas entre os tributários Negro e Madeira, Amazônia Central \\ Eliezer Senna Gonçalves Júnior ${ }^{1,2 *}$, Emílio Alberto Amaral Soares², \\ Sonia Hatsue Tatumi ${ }^{3}$, Marcio Yee ${ }^{3}$, Juan Carlos Ramirez Mittani ${ }^{3}$
}

\begin{abstract}
In the scope of Solimóes-Amazon fluvial system between the Negro and Madeira tributaries, three levels of Quaternary fluvial terraces overlie the Alter do Chão and Novo Remanso formations further than $100 \mathrm{~km}$ southward its current main channel. Smooth undulated topography presenting low drainages density formed by sparse secondary plain channels and rounded lakes characterizes these deposits. Internally, they show point bars morphology constituted by intercalated layers of mud (silt and clay) and sand forming an inclined heterolithic stratification. The asymmetric distribution of fluvial terraces allied to the records of old scroll-bars features and paleochannels in many extensions of the Solimōes River suggests the predominance of a meander pattern between 240 to 6 kyears. On the other hand, the development of the current anabranching pattern took place in the last six kyears due to the Holocene sea-level rise, besides the action of neotectonics and rainforest establishment related to the increase of humidity in Amazonia.
\end{abstract}

KEYWORDS: Amazonian continental Quaternary; Solimōes-Amazon fluvial system; Amazon basin.
RESUMO: No trecho do sistema fluvial Solimöes-Amazônia que compreende os tributários Negro e Madeira, três niveis de terraços fluviais Quaternários recobrem as rochas das formaçóes Alter do Chão e Novo Remanso por mais de $100 \mathrm{~km}$ ao sul do principal canal atual. Esses depósitos são caracterizados por uma topografia suavemente ondulada apresentando baixa densidade de drenagens, formadas por canais secundários esparsos e lagos arredondados. Internamente, apresentam morfologias de barras em pontal constituidas por intercalação de camadas de lama (silte e argila), além de areia, formando pares de estratificaçōes heteroliticas inclinadas. A predominância de um padrão meandrante há 240.000 e 6.000 anos é sugerida pela distribuição assimétrica dos terraços fluviais, aliada aos registros de antigas barras em pontal e paleocanais em diversos trechos do Rio Solimôes. Por outro lado, o desenvolvimento do atual padrão anabranching se iniciou nos últimos 6.000 anos em virtude da subida do nivel do mar no Holoceno, além da ação de eventos neotectônicos e o estabelecimento da floresta tropical, que está relacionado ao aumento da umidade na Amazônia.

PALAVRAS-CHAVE: Quaternário continental da Amazônia; sistema fluvial Solimóes-Amazônia; bacia do Amazonas.

${ }^{1}$ Departamento Nacional de Produção Mineral, Superintendência do Amazonas, Manaus (AM), Brazil. E-mail: eliezer.junior@dnpm.gov.br 2Programa de Pós-Graduação em Geociências, Universidade Federal do Amazonas, Manaus (AM), Brazil. E-mail: easoares@ufam.edu.br 33niversidade Federal de São Paulo, Santos (SP), Brazil. E-mails: sonia.tatumi@unifesp.br, marcioyee@hotmail.com, juan.mittani@gmail.com *Corresponding author.

Manuscript ID: 20160009. Received in: 01/13/2016. Approved in: 05/16/2016 


\section{INTRODUCTION}

In the extent of the Solimóes-Amazon fluvial system, between Negro and Madeira tributaries, the post-Miocene deposits related to channels and marginal areas of the largest Amazonian rivers cover parts of the Cretaceous and Miocene units of the Amazon Sedimentary Basin (Dino et al. 2006; 2012, Dantas \& Maia 2010, Soares et al. 2010). However, in spite of their relevance to the local landscape, there is no formal standard for these deposits. Over the years, they have received different denominations and diffuse geological boundaries in many studies (Latrubesse \& Franzinelli 2002, Rossetti et al. 2005, Riker et al. 2008, Soares 2007, Rozo et al. 2012), and were occasionally associated with Solimôes and Iça Formations (Latrubesse \& Franzinelli 2002, Rossetti et al. 2005).

Thereby, one of the reasons for the lack of formal stratigraphic standards to these post-Miocene deposits in the Amazon Basin is the reduced number of sediment burial ages. Hence, some authors have been successfully using the optically stimulated luminescence (OSL) to determine fluvial terraces ages in Central Amazon (Soares et al. 2010, Rozo et al. 2012, Fiore et al. 2014). This has been done due to the higher chronological range in comparison with radiocarbon, as well to the dismissive availability of organic matter (Tatumi et al. 2008, Fiore et al. 2014).

Regarding the relative low volume of post-Miocene deposit ages, many investigations focused on fluvial dynamics and geomorphological features in order to understand the development of the Solimóes-Amazon fluvial system, thus indicating the currently predominance of a very stable anastomosing pattern (Mertes et al. 1996, Latrubesse \& Franzinelli 2002, Rossetti et al. 2005, Rozo et al. 2012). On the other hand, some authors support the prevalence of an anabranching fluvial style in Solimóes-Amazon system in the present days (Latrubesse 2008, Soares et al. 2010, Passos et al. 2012). According to Nanson \& Knighton (1996), the generic term 'anabranching river' is applied to any type of multiple channel systems with stable alluvial islands dividing the flow, whereas the term anastomosed river is associated with a specific subset of low-energy anabranching system. Thus, Rozo et al. (2012) concluded that the current conformation of the Amazon River could be considered both anastomosing and anabranching.

Paleochannels and scroll-bar sets have been recognized in Solimóes-Amazon system alluvial plain in many different reaches (Mertes et al. 1996, Latrubesse \& Franzinelli 2002, Rozo 2004, Soares 2007, Soares et al. 2010, Teixeira \& Soares 2011, Rozo et al. 2012, Gonçalves Junior et al. 2014). However, there is still no consensus about the meaning of these meander-related features. Rozo (2004), Soares et al. (2010) and Teixeira \& Soares (2011) suggest the prevalence of a single meander channel that gradually evolves to an anastomosed river along the Pleistocene, whereas Latrubesse \& Franzinelli (2002) and Rozo et al. (2012) assign the alluvial plain meander characteristics to the activity of secondary channels in a multiple-channel river system.

In the present study, the geomorphologic analysis allied to the OSL dating of fluvial terraces southward the Solimóes-Amazon River in the extension between Negro and Madeira tributaries, grounds the construction of a model for the local landscape evolution, since the Middle Pleistocene until the present days.

\section{GEOLOGICAL SETTING}

The Quaternary sedimentation in the Solimóes-Amazon fluvial system spread between Negro and Madeira tributaries is mostly related to channel areas and alluvial plains (Soares et al. 2010) that cover Alter do Chão (Kistler 1954) and Novo Remanso Formations (Rozo et al. 2005, Dino et al. 2012).

According to Latrubesse \& Franzinelli (2002), the lower Solimóes River alluvial deposits can be divided into three different units, considering their geomorphological and sedimentological features:

1. the older scroll-dominated plain formed by a Late Pleistocene silt-clay rich terrace bearing a well-developed morphology of scroll bars;

2. the impeded floodplain that is eventually inundated by annual floods and characterized by round or irregular-shaped lakes and grey-greenish muddy sediment deposits; and

3. channel-dominated floodplain, gathering current fluvial channel bars, levees and present-day scroll bars deposits.

In a study carried out in the area between the BrazilianPeruvian border up to the Amazon River outflow, Rossetti et al. (2005), based on radiocarbon $\left({ }^{14} \mathrm{C}\right)$ data, proposed the existence of four different levels of Quaternary deposits. They are laterally discontinuous and perpendicularly settled to the Solimóes and Amazon rivers, informally called Q1 (43.7 to 37.4 kyears), Q2 ( -27.2 kyears), Q3 (6.73 to 2.48 kyears), and Q4 (280 to 130 years).

On the other hand, Soares et al. (2010), mainly using OSL data, found ages varying from 65,200 to 7,500 years for fluvial terraces along the Solimôes River, between Manaus and Manacapuru, which are disposed in parallel strips along the main channel and extending for tens of meters. Additionally, Fiore et al. (2014) determined ages from 205,000 to 83,000 years associated with fluvial deposits in the confluence of Solimôes and Purus rivers.

Recently, Rozo et al. (2012) found four different morphostratigraphic units in the Amazon River alluvial plain, between Negro and Madeira rivers, based on OSL data. They include: 
1. terraced deposits represented by Alter do Chão and Novo Remanso Formations, which bear elongated-ramified lakes commonly mouth-damned;

2. scroll bars deposits (7,500 to 3,400 years old) that shape most alluvial islands and part of the right bank of the Amazon River, represented by successive intercalations of silty fine-grained sand and grayish clay layers that form inclined heterolithic stratification (IHS) pairs;

3. floodplain deposits (1,100 to 990 years old) made up by greyish to brown organic matter-rich, laminated and massive clays, characterized by a very flat surface holding irregularly rounded and oxbow lakes; and, finally,

4. the channel bar deposits represented by present-day fine-grained sandy Amazon River channel bars, oriented along the current main flow direction.

Despite the major influence of sedimentological, geomorphological, and environmental dynamics in the development of the landscape and drainage systems in Central Amazon, some authors have observed the role of neotectonics in those processes through the operation of an E-W transcurrent dextral system (Franzinelli \& Igreja 1990, Igreja 1998, Igreja et al. 1999). This system probably reactivated old structures (Costa et al. 1996) and enabled the formation of half-grabens, which accommodated the largest part of the post-Miocene sedimentation in Central Amazon (Fernandes Filho 1996, Silva et al. 2007, Franzinelli \& Igreja 2011, Igreja 2012). Thus, they caused the straightening of rivers segments (Latrubesse \& Franzinelli 2002), and modeled the local landscape.

\section{MATERIAL AND METHODS}

Geomorphological analysis of the study area was performed using a 6-m-spatial resolution of synthetic aperture radar images provided by Centro Gestor e Operacional do Sistema de Proteção da Amazônia (CENSIPAM). It sought to identify the largest lineaments, the secondary channels that straighten segments, the main morphological features of the fluvial terraces, and geological boundaries of the studied units.

For the OSL dating procedures, 23 samples were collected from the top sandy layers of the fluvial terraces point bars through aluminum tubes of $50 \mathrm{~cm}$ long and a $7 \mathrm{~cm}$ diameter. A single aliquot regenerative (SAR) dose protocol (Murray $\&$ Wintley 2003) was applied on the quartz-rich samples (Fig. 1). No significant signal in the infrared stimulated luminescence (IRSL) analysis confirmed the absence of feldspar grains in the aliquots. The protocol application firstly requires a previous sieving in order to attain 180 to $250 \mu \mathrm{m}$-sized grains followed by four hours of $\mathrm{H}_{2} \mathrm{O}_{2}$ treatment to eliminate organic matter. Then, 45 minutes of hydrofluoridric acid (HF) $20 \%$ exposure to eliminate external alpha ionization contribution, two hours of HCL $20 \%$ with the purpose of carbonates and fluorites removal and, finally, heavy liquid treatments (Sodium Polytungstat - SPT) in order to separate the quartz grains from the heavy minerals (density $=2.85$ ), and the feldspar from quart grains (density $=2.58$ ).

The OSL measurements were performed through a Ris $\varnothing$ TL/OSL reader, model DA-20 (DTU National Laboratory for Sustainable Energy). Blue light was applied for quartz stimulation with one to five seconds of integration limits and background calculation of 200 to 250 seconds. The best pre-heat temperature obtained through dose recovery test was $220^{\circ} \mathrm{C}$, and the test results indicated $10.3 \pm 0.5$ Gy recovered dose. Hoya U-340 optical filter was used for the OSL signal detection. Radionuclides concentrations for dose rate calculation were measured through gamma spectroscopy with the $\mathrm{NaI}(\mathrm{Tl})$ detector, model 802, Canberra Industries Inc., and standard soils samples JR-1, JG-1a, JB-3 and JG-3. The measurements were performed with about $100 \mathrm{~g}$ of the

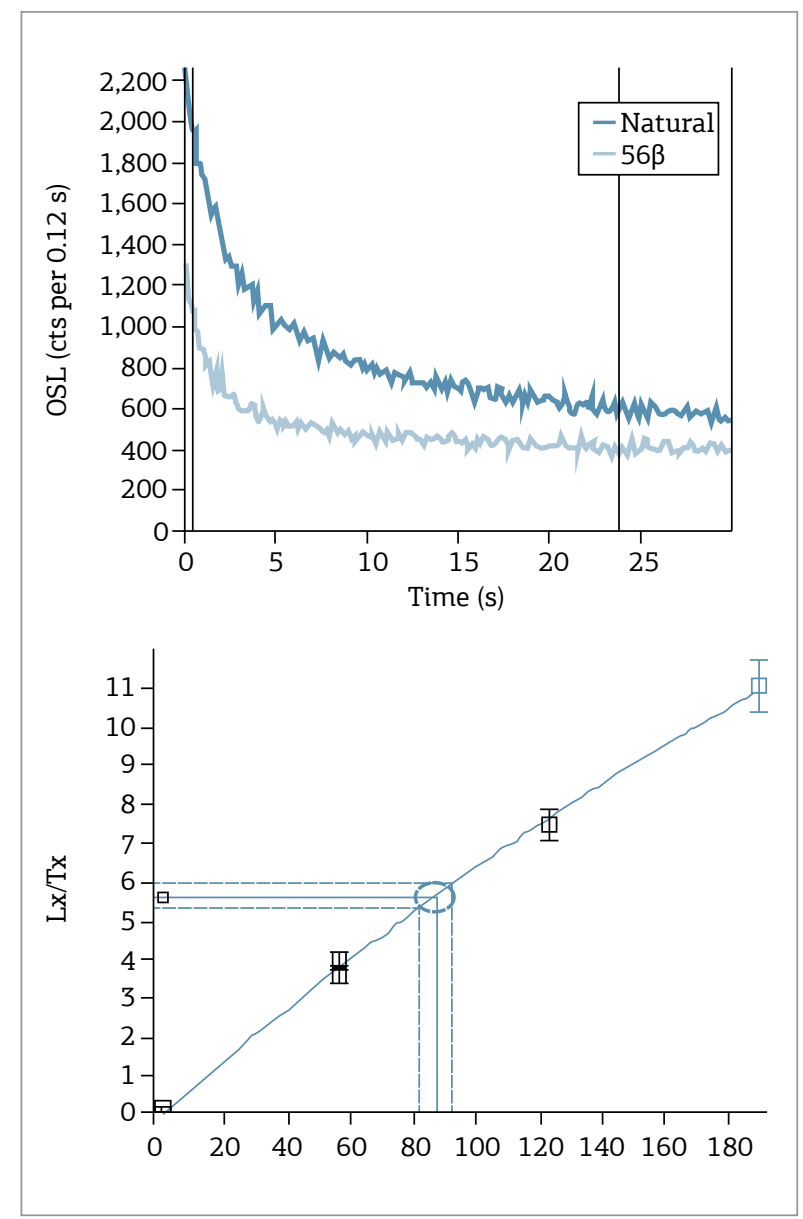

Figure 1. Examples of optically stimulated luminescence (OSL) decay and dose response curve. 
sediment, which had been previously stored and sealed in a plastic container for two weeks to assure the secular equilibrium. Water content was also measured for the annual dose rate correction. Field gamma-ray spectra were collected using a Canberra Portable Plus $\gamma$ - spectrometry system model 802, equipped with a $2 \times 2$ inch $\mathrm{NaI}(\mathrm{Tl})$ detector. The measurements were performed with the equipment placed at $1.5 \mathrm{~m}$ from the ground, and the detector was calibrated according to the procedure described by Murray (1981).

In order to avoid the natural contributions of radionuclides from the soil, the measurements were performed over Guamá River for eight hours. For calculating the annual dose rate, the integral count rate must be converted into counts per area and time $\mathrm{N}$, divided by the effective area of the $\mathrm{NaI}$ crystal. For the standard rock, the dose rate is: $\mathrm{D}=9.37 \mathrm{~N}$, in which $\mathrm{D}$ is in $\mathrm{Gyka}^{-1}$ and $\mathrm{N}$ in counts/cm-2s-1 (Prescott \& Clay 2000). Cosmic ray dose rates for luminescence and Electron Spin Resonance (ESR) dating are measured with a scintillation counter. The water content in the samples fluctuated from 0.69 to $1.11 \%$, however the variations of water between the seasons was not found.

\section{RESULTS}

\section{Morphostratigraphic units}

Geomorphological analysis from radar images based on depositional morphology of the Solimóes-Amazonas River fluvial terraces, on secondary drainage patterns in alluvial plain and relief features, allied to field sampling, supported the definition of three distinct Quaternary fluvial terrace levels, surrounding a few older cores of Alter do Chão and Novo Remanso Formations.

\section{Alter do Chão and Novo Remanso Formations}

Situated between 100 and 50 meters above sea level, Alter do Chão and Novo Remanso Formations consist of elongated cores that are laterally limited by lineaments visible from satellite images, which are mainly pointed NE-SW and NW-SE. White to reddish, occasionally rusty colored, sandstones, mudstones and conglomerates make up these units. They show a peculiar geomorphology represented by a dissected relief forming hills and plateaus held up by ferruginous lateritic paleosoil levels.

\section{Quaternary morphostratigraphic units}

The Quaternary fluvial terraces of Solimóes-Amazon system, between Negro and Madeira tributaries, are asymmetrically distributed and arranged as elongated stripes following the river channel and smoothly South to North raked. They can be divided into three distinct levels herein informally denominated as Upper Terrace (UT), Intermediate Terrace (IT) and Lower Terrace (LT), according to their geomorphological (Fig. 2) and geochronological features (Tab. 1, Fig. 3).

\section{Upper Terrace}

The UT occupies most of the study area and represents the older morphostratigraphic unit of Solimóes-Amazon fluvial system alluvial plain, presenting OSL ages varying between $240,000 \pm 16,000$ and $51,000 \pm 5,000$ years (Tab. 1). Currently, this unit occurs far enough from the modern main channel, free of its annual floods and presenting a moderately dissected geomorphological pattern, which is associated with the predominance of sub-rectangular to sub-dendritic drainage types (Fig. 2). Pedogenesis processes enabled the occurrence of a metric orange clay soil layer that allows the installation of large trees over these deposits (Fig. 4).

Preserved old point bars lead to the development of a sequence of smooth valleys and undulations (Fig. 5) that reach up to 80 meters above sea level in the South of the study area, decreasing northward and coming down to merely 30 meters above sea level, near the contact with the younger Quaternary deposits.

Blockage of the lower course of secondary drainages caused by factors such as levees deposits, rise of the main channel water level and, occasionally, the tectonic uplift, formed elongated and branched lakes over the UT surface.

Internally, intercalations in different proportions of whitish to reddish mud and yellowish to reddish sandy layers form IHS pairs (sensu Thomas et al. 1987) in the remaining point bars features (Fig. 6).

\section{Intermediate Terrace}

With OSL ages varying from $30,900 \pm 8,000$ to $19,100 \pm$ 6,300 years, the IT is disposed as a continuous elongated strip parallel to the Solimôes-Amazon fluvial system main channel (Fig. 2), which is eventually being subject to the annual floods.

This unit presents a very flat relief (Fig. 7) containing rare features of accretion lines that are only observed through high-definition radar images. Its elevations vary from 30 to 25 meters above sea level, thus showing a smooth northward decreasing trend, more precisely, towards the main channel. The deposits are mostly formed by thick greyish to brownish silty mud layers intercalated by infrequent metric greyish sand layers, composing IHS pairs. The IT surface is transected by sparse secondary plain channels known as 'furos' and 'paranás', which detach parts of this unit, such as the Careiro Island, where portions of IT were isolated and later bordered by point bars of younger units. Additionally, some kilometric rounded or elliptical oxbow lakes, commonly interconnected by intermittent secondary channels, compose the drainage system of the IT. 


\section{Lower Terrace}

Near $18,300 \pm 4,000$ to $2,000 \pm 1,000$ years, LT deposits occur mostly as elliptical-shaped islands and sometimes as elongated thin strips on the Solimóes-Amazon-Madeira fluvial system banks (Fig. 2). Their relief is plain with elevations between 25 and 10 meters above sea level, containing a few mild undulations formed by sequences of crests and depressions related to kilometric bent accretion lines.

Currently, LT deposits are totally subject to annual floods, and their drainage system is based on narrow lakes formed between the accretion lines and some $200 \mathrm{~m}$ wide secondary channels ('furos' and 'paranás'). The surface is covered by small vegetation, mainly made up by grasses and shrubs, seated on a thin undeveloped soil layer that was originated by hydromorphic processes.

Internally, the deposits are composed of intercalations of metric dark-brown silty layers and sub-metric light grey, well selected and fine-grained sandy layers that together make up IHS pairs (Fig. 8).

Some preserved sedimentary structures, like planar bedding, cross-stratification and, in a few cases, flaser bedding, are observed. Furthermore, bioturbation records represent the post-sedimentary features found on the deposits. Occasionally, younger dark grey centimetric organic matter-rich (partially decomposed pieces of trunks, roots, and leaves) mud layers overlay the IHS pairs.

\section{Tectonic features}

The tectonics performs a relevant factor of landscape transformation and geomorphological evolution in the studied Pleistocene deposits. Tens of kilometers lineaments, observed by radar images, mold the largest part of the Solimóes-Amazon system riverbanks and are responsible for the fluvial capture processes on secondary plain channels. Furthermore, these structures contour and shape many relicts of Alter do Chão and Novo Remanso Formations placed in the alluvial plain, sustained by levels of paleosoils and lateritic crusts.

These lineaments show two dominant trends controlling most of the secondary drainages in the alluvial plain of the study area: N40-55E and N50-65W, being compatible to the structures pointed by Costa et al. (1996), controlling the Madeira River channel, and those marked by

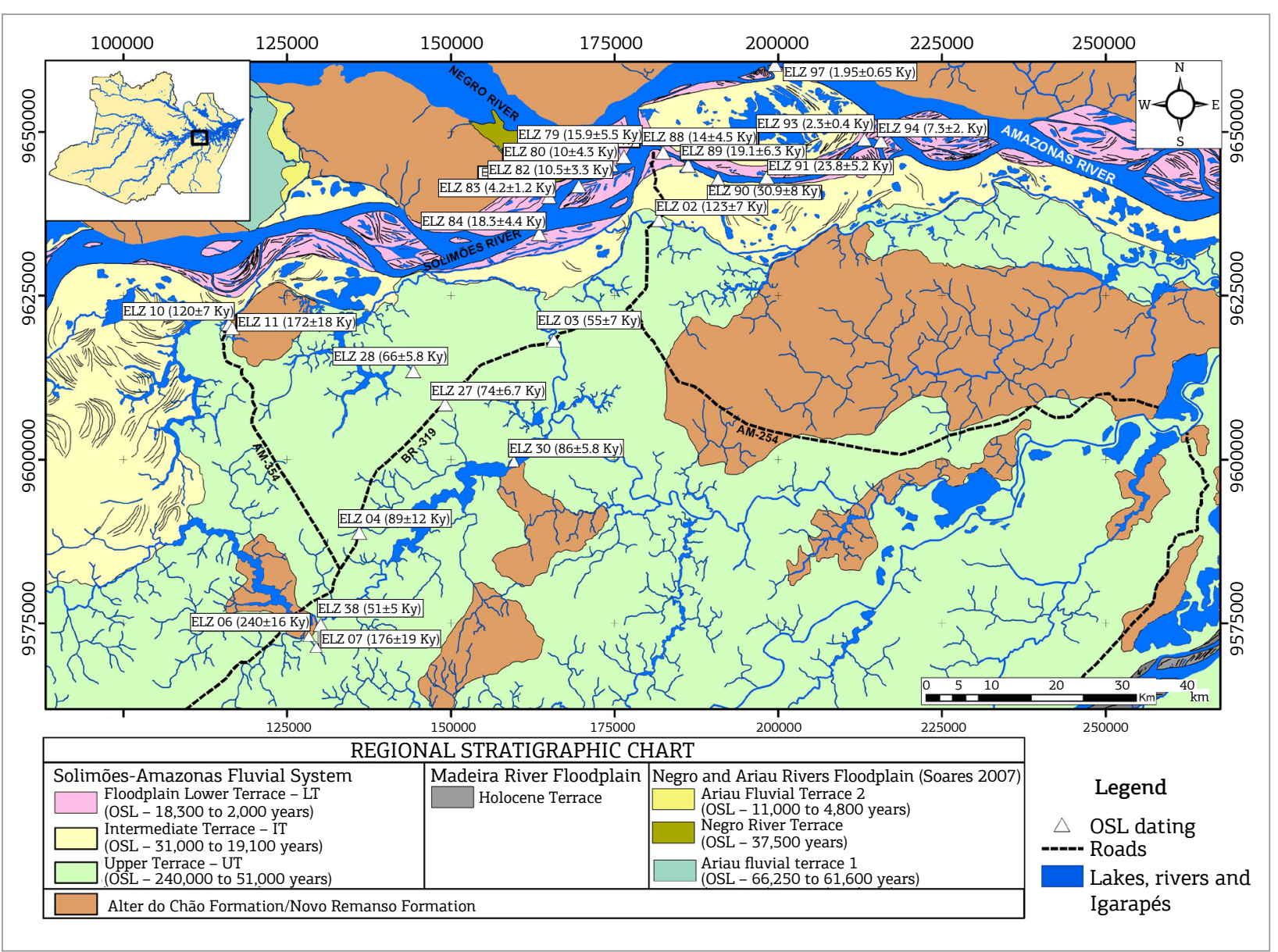

Figure 2. Study area geological map with optically stimulated luminescence (OSL) results. 
Franzinelli \& Igreja (2011), limiting the Careiro-Island margins at the Solimóes-Amazon system channel. Moreover, the intersections of lineaments make up many rhombohedral basins, resembling the grabens of Paciência and Careiro described by Franzinelli \& Igreja (2011) and Igreja (2012), which accommodated part of the Holocene sediments in the Solimóes River channel on the studied reach.

As observed by radar images, the N40-55E lineaments control part of the right margin of the Solimóes-Amazon system in the studied extent, and they are linked to the direction of lotic water bodies in the alluvial plain. On the other hand, the N50-65W lineaments are majorly responsible for inflecting the secondary plain channels through short segments (Fig. 9), thus increasing the hydraulic gradient and forming limits of linear lakes in those rivers. Two less prominent directions, N65-75E and E-W, represent scattered smaller lineaments in the alluvial plain and control third-order drainages.
Additionally, the direction control of the right banks of Solimóes River associated with the pattern of bypasses of the secondary plain channels suggests the predominance of a dextral kinematic related to the NE, NW and E-W structures, as can be seen in Fig. 9.

\section{DISCUSSION}

\section{Evolution of the Solimões-Amazon fluvial system in the Quaternary}

Large scale scroll bars and IHS depositional morphology preserved in the alluvial plain on the studied reach of the Solimóes-Amazonas system, besides the record of at least five paleochannels with tens of kilometers, which truncate the fluvial terraces upstream the studied area (Mertes et al. 1996, Latrubesse \& Franzinelli 2002, Teixeira \& Soares 2011), suggest the occurrence of large periods of avulsion and

Table 1. Concentrations of radioactive isotopes, equivalent dose, annual dose rate, and ages through the single aliquot regenerative protocol.

\begin{tabular}{|c|c|c|c|c|c|c|c|}
\hline Sample & $\mathrm{U}(\mathrm{ppm})$ & Th (ppm) & K (\%) & $n_{0} / n$ & $D_{e}(G y)$ & $A D(\mu G y / a)$ & $\begin{array}{c}\text { Age (ky) } \\
\text { SAR }\end{array}$ \\
\hline ELZO2 & $2.69 \pm 0.55$ & $7.12 \pm 0.26$ & $0.07 \pm 0.01$ & $12 / 7$ & $232 \pm 19$ & $1931 \pm 402$ & $123 \pm 7$ \\
\hline ELZO3 & $6.26 \pm 0.61$ & $14.42 \pm 0.52$ & - & $12 / 7$ & $149 \pm 14$ & $2708 \pm 213$ & $55 \pm 7$ \\
\hline ELZO4 & $2.34 \pm 0.87$ & $7.12 \pm 0.26$ & $0.49 \pm 0.07$ & $12 / 7$ & $235 \pm 47$ & $3002 \pm 406$ & $89 \pm 12$ \\
\hline ELZO6 & $0.25 \pm 0.03$ & $2.62 \pm 0.09$ & - & $12 / 7$ & $233 \pm 16$ & $972 \pm 218$ & $240 \pm 16$ \\
\hline ELZO7 & $0.61 \pm 0.05$ & $2.29 \pm 0.08$ & - & $12 / 7$ & $166 \pm 33$ & $895 \pm 96$ & $176 \pm 19$ \\
\hline ELZ10 & $2.99 \pm 0.80$ & $11.62 \pm 0.42$ & $3.06 \pm 0.44$ & $12 / 7$ & $192 \pm 41$ & $1765 \pm 264$ & $120 \pm 7$ \\
\hline ELZ11 & $0.59 \pm 0.03$ & $3.74 \pm 0.13$ & - & $12 / 7$ & $112 \pm 25$ & $890 \pm 143$ & $172 \pm 18$ \\
\hline ELZ 27 & $1.87 \pm 0.06$ & $6.63 \pm 0.14$ & $0.61 \pm 0.01$ & $12 / 7$ & $132 \pm 12$ & $1842 \pm 17$ & $74 \pm 6.7$ \\
\hline ELZ 28 & $1.64 \pm 0.05$ & $7.02 \pm 0.17$ & $0.40 \pm 0.01$ & $12 / 10$ & $102 \pm 9$ & $1592 \pm 15$ & $66 \pm 5.8$ \\
\hline ELZ 30 & $1.73 \pm 0.06$ & $11.00 \pm 0.28$ & $0.010 \pm 0.001$ & $12 / 7$ & $126 \pm 9$ & $1564 \pm 18$ & $86 \pm 5.8$ \\
\hline ELZ 38 & $1.27 \pm 0.05$ & $6.30 \pm 0.11$ & $1.20 \pm 0.02$ & $12 / 8$ & $112 \pm 11$ & $2262 \pm 18$ & $51 \pm 5$ \\
\hline ELZ 79 & $1.34 \pm 0.07$ & $2.11 \pm 0.07$ & - & $24 / 16$ & $12.0 \pm 0.5$ & $755 \pm 233$ & $15.9 \pm 5.5$ \\
\hline ELZ 80 & $1.26 \pm 1.14$ & $2.96 \pm 0.10$ & - & $24 / 20$ & $8.0 \pm 0.4$ & $798 \pm 305$ & $10.0 \pm 4.3$ \\
\hline ELZ 82 & $1.22 \pm 0.86$ & $1.82 \pm 0.06$ & $0.34 \pm 0.04$ & $24 / 24$ & $11 \pm 0.5$ & $1047 \pm 278$ & $10.5 \pm 3.3$ \\
\hline ELZ 83 & $1.31 \pm 0.62$ & $1.71 \pm 0.06$ & - & $24 / 18$ & $3.0 \pm 0.2$ & $716 \pm 165$ & $4.2 \pm 1.2$ \\
\hline ELZ 84 & $1.25 \pm 0.54$ & $2.59 \pm 0.09$ & - & $24 / 20$ & $14.0 \pm 0.7$ & $766 \pm 145$ & $18.3 \pm 4.4$ \\
\hline ELZ 88 & $1.4 \pm 0.80$ & $1.96 \pm 0.07$ & - & $24 / 20$ & $11.0 \pm 0.6$ & $782 \pm 212$ & $14.0 \pm 4.5$ \\
\hline ELZ 89 & $1.06 \pm 0.67$ & $1.64 \pm 0.06$ & $0.006 \pm 0.001$ & $24 / 18$ & $12.5 \pm 0.7$ & $656 \pm 182$ & $19.1 \pm 6.3$ \\
\hline ELZ 90 & $0.79 \pm 0.46$ & $1.66 \pm 0.06$ & - & $24 / 21$ & $18 \pm 0.9$ & $581 \pm 122$ & $30.9 \pm 8.0$ \\
\hline ELZ 91 & $1.03 \pm 0.37$ & $0.59 \pm 0.02$ & $0.005 \pm 0.001$ & $24 / 15$ & $13.5 \pm 0.7$ & $567 \pm 96$ & $23.8 \pm 5.2$ \\
\hline ELZ 93 & $1.93 \pm 0.40$ & $4.27 \pm 0.15$ & $0.67 \pm 0.09$ & $12 / 11$ & $4 \pm 0.2$ & $1760 \pm 216$ & $2.3 \pm 0.4$ \\
\hline ELZ 94 & $3.11 \pm 0.11$ & $1.30 \pm 0.69$ & - & $12 / 12$ & $6 \pm 0.3$ & $820 \pm 189$ & $7.3 \pm 2.0$ \\
\hline ELZ 97 & $0.54 \pm 0.07$ & $0.78 \pm 0.03$ & - & $12 / 9$ & $6 \pm 2$ & $3078 \pm 281$ & $2.0 \pm 1.0$ \\
\hline
\end{tabular}

SAR: single aliquot regenerative protocol; De: equivalent dose; Adc.r: annual dose rate. 
resumption of the sedimentation in the Solimóes-Amazon fluvial system. The combination of these features supports the hypothesis of a meandering pattern prevalence in the past, despite the currently anabranching style.

The term anabranching was assumed in the present work to refer to the currently pattern of the studied extent of Solimóes-Amazon fluvial system due to the occurrence of many secondary meandering channels, differing from regular anastomosed rivers, which are laterally stable (Smith \& Putman 1980) and with no major secondary contribution of channels. In addition, Nanson \& Knighton (1996) emphasize the anastomosed pattern to be limited to a specific low energy branch-channeled subset that is very often associated with fine-grained sediments deposition and the presence of organic matter, differing from the studied river reach, which presents some fluvial pattern variations and a relevant presence of sandy sediments.

Latrubesse \& Franzinelli (2002) proposed the possible prevail of a secondary meandering system of channels forming the older floodplain of Solimóes River during the Late Pleistocene; however, they attributed the ${ }^{14} \mathrm{C} \mathrm{1,030 \pm}$ 50 and $310 \pm 50$ years-dated younger scroll bars formation to the modern anastomosed pattern, thus they did not determine the exact point of change. More recently, Rozo et al. (2012), based on OSL data, affirmed that the anastomosed style has already been consolidated around 7,500 \pm 850 and $3,400 \pm 600$ years, thus forming the islands complexes on the main channel of the Amazon River, while the development of the scroll bars on the alluvial plain was due to the secondary meandering channels activity.

Considering the OSL data attained in the present work, the development of the Quaternary fluvial terraces in the studied reach of the Solimóes-Amazon system may have started linked to a meandering river around $240,000 \pm 16,000$ ago. This fact is corroborated by OSL maximum 204,600 \pm 54,600 years recorded by Fiore et al. (2014) for related fluvial terraces located tens of kilometers Westward the study area, near the Purus River outflow.
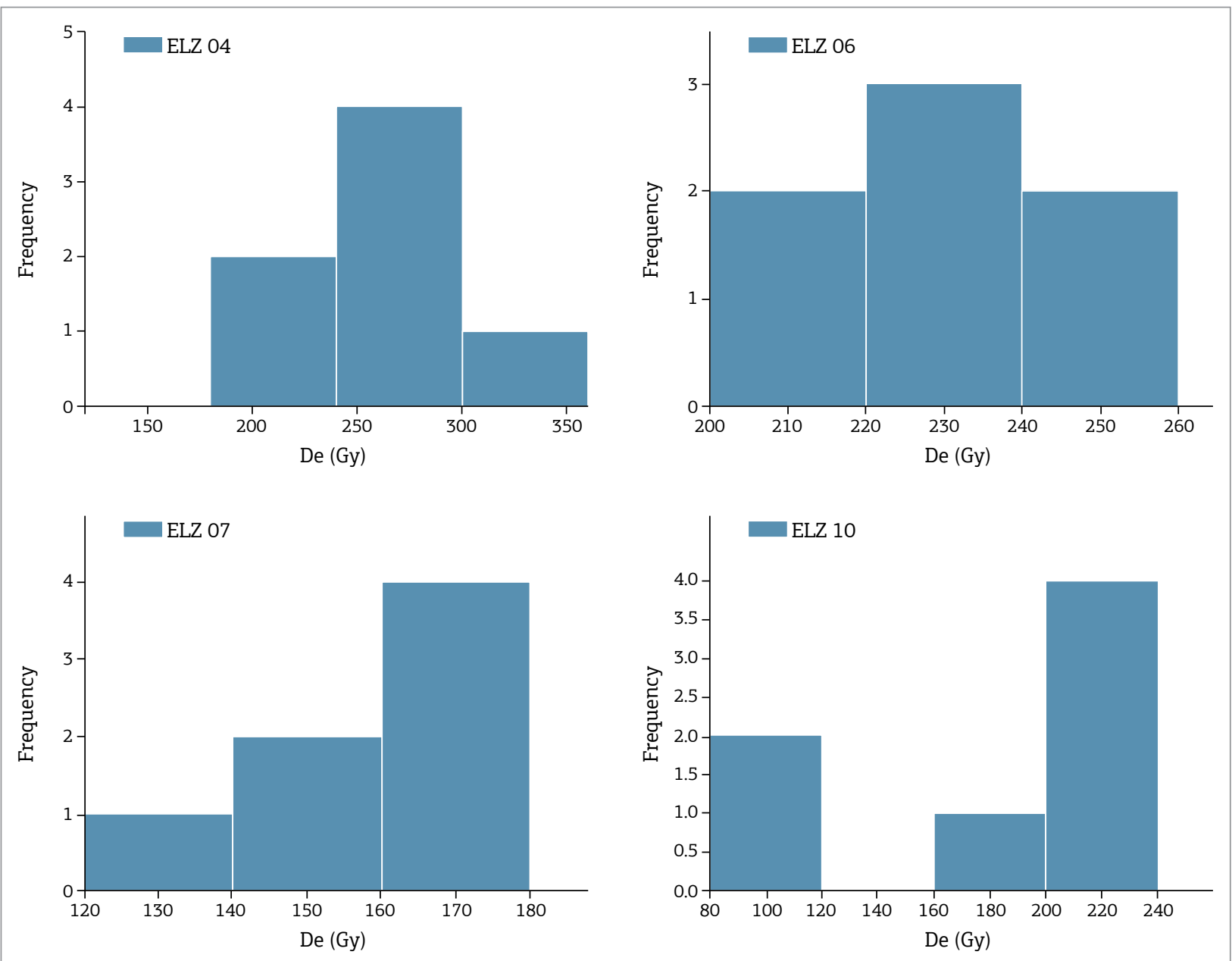

Figure 3. Histograms of fluvial terraces older level ages (single aliquot regenerative - SAR protocol). 
The meandering fluvial pattern was probably developed with a high sinuosity single-channel and strong lateral migration that is usual to this type of rivers, as described by Riccomini et al. (2000). Soares (2007) suggested the low stability of the Solimôes-Amazon riverbanks enabled the intense lateral migration of the meandering channel during the Upper Pleistocene, due to the low aggradation rates caused by sea level decrease and low subsidence rates (Wright \& Marriott 1993 and Zhang et al. 1997). In this way, Irion et al. (1997) recorded a decrease of sea level, between 120,000 and 18,000 years ago.

At some point in Early to Middle Holocene (sensu Walker et al. 2012), the fluvial system began a gradational change to the present anabranching pattern, with secondary contribution of channels, due to the combination of the regional base level rise, the environmental changes during the Holocene, and the tectonic action (Soares 2007).

The regional base level change is probably associated with the blockage of the Amazon river outflow (Irion et al. 1997, Soares 2007) caused by a global gradual sea level rise, which started at the end of Upper Pleistocene related to the beginning of the current interglacial age. The sea level arrived its largest global mark at the Middle Holocene (sensu Walker et al. 2012), around 6,000 to 5,000 years BP, as recorded by Vieira (1981), Irion et al. (1997), Mörner (2005), and Rossetti et al. (2005).

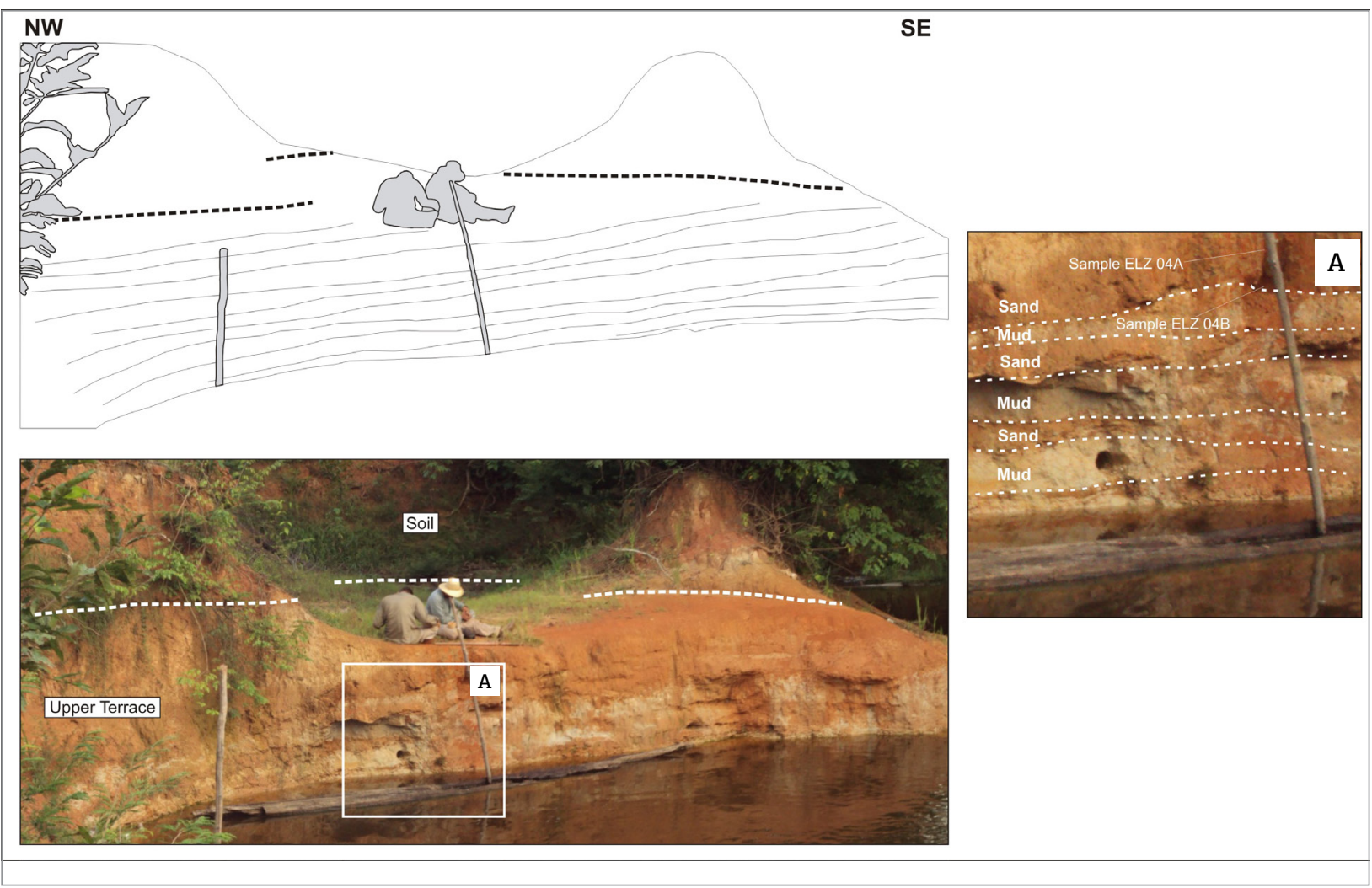

Figure 4. Upper terrace outcrop covered by a thick clay soil layer in left margin of BR-319 road, near Careiro-Castanho city. Internally, the unit contains sand and mud intercalated layers showing inclined heterolithic stratification.

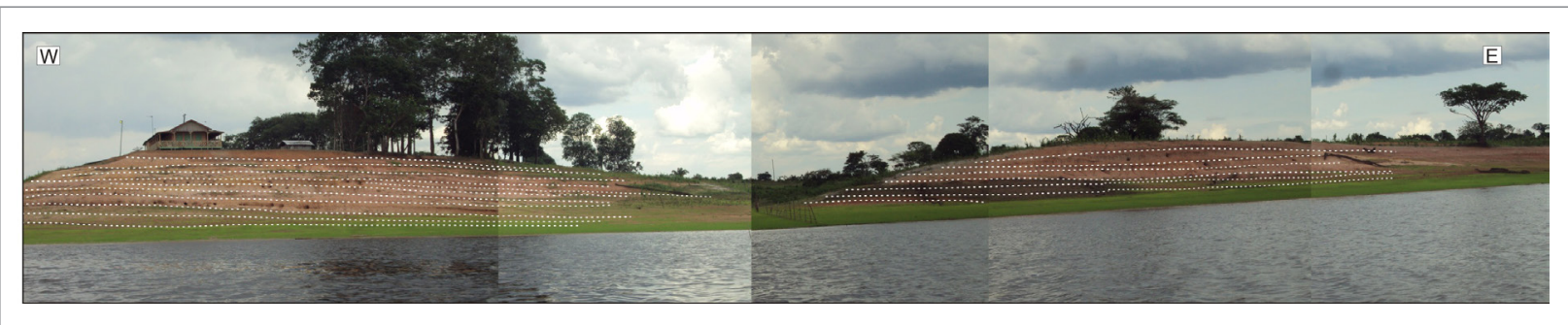

Figure 5. Sequence of smooth undulations and valleys on Mamori Lake left brim, showing the preservation of old point bars with inclined heterolithic stratification features making up the typical morphology of the Upper Terrace. 
Thus, the gradual base level rise associated with the tilting of tectonic blocks southward the SolimóesAmazon alluvial plain suggested by Soares (2007), led to the generation of accommodation space and consequent increase of channel-bed aggradation (Zhang et al. 1997, Blum \& Törniqvist 2000). These factors were involved in the reduction of channel flow velocity and increment of suspended fine sediments load, leading to the development of more cohesive riverbanks, thus restricting the migration of the meander channel and favoring the stabilization of the river course, a remarkable feature of anabranching rivers.

In addition, Wright \& Marriott (1993) pointed out that fluvial systems are substantially variable and respond even to low intensity climatic and tectonic changes. Thus, approximately at the same time the sea level reached its largest mark in Holocene palynological, evidence showed the increasing rates of humidity in Central Amazon around 5,000 to 4,000 years ago (Latrubesse \& Franzinelli 1993, Baker et al. 2001 and Rossetti et al. 2005). In this sense, Behling et al. (2010) and Behling (2011) remarked increment phases of varzea and Igapó vegetation at 4,610 and 2,060 years BP, favoring the phytostabilization of the riverbanks and consequent major contribution of more cohesive fine sediments in the suspended load.

The neotectonics probably developed a secondary role in the fluvial pattern shift, enabling the accommodation of the Holocene sediments at Paciência, Manaus and Careiro rhombograbens (Franzinelli \& Igreja 2011, Igreja 2012) in the Solimôes-Amazonas River floodplain and Tubinambarana lineament (Costa et al. 1996), which fits the Madeira River and its fluvial terraces. Igreja (2012) registered sedimentation rates varying from 2 to $7 \mathrm{~mm}$ per year in Careiro Island in the last 2,840 years, whereas Rozo et al. (2012) recorded $1.1 \mathrm{~mm}$ per year over the last 7,500 years, confirming the tendency of space generation by subsidence in the basin. Additionally, Soares (2007) suggested the

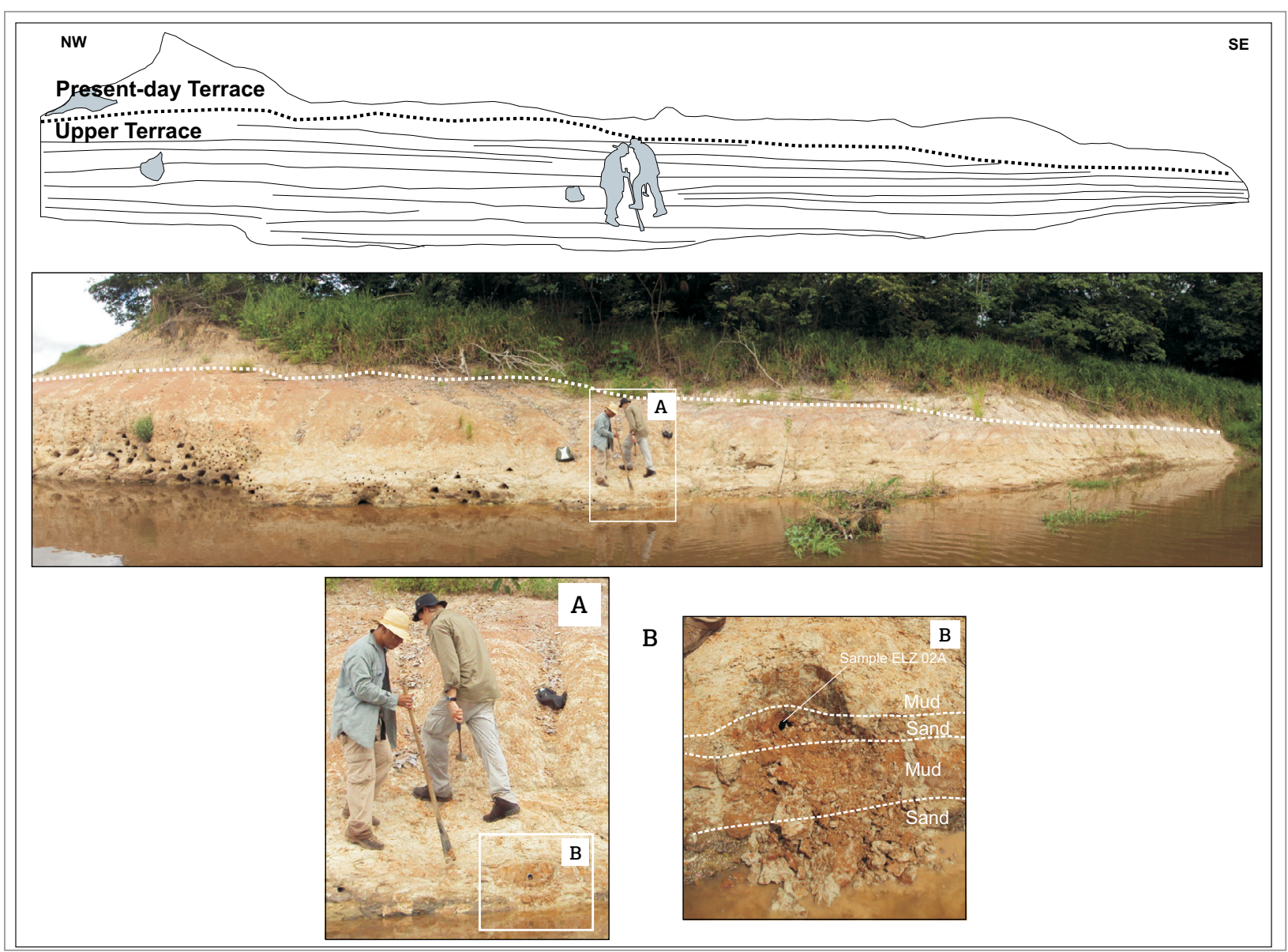

Figure 6. Intercalations of fine sand and mud layers forming inclined heterolithic stratification on the Upper Terrace outcrop located at the right margin of the Paraná Comprido. The older deposit is partially covered by a present-day terrace formed as the result of recent evolution of the tributary river. 


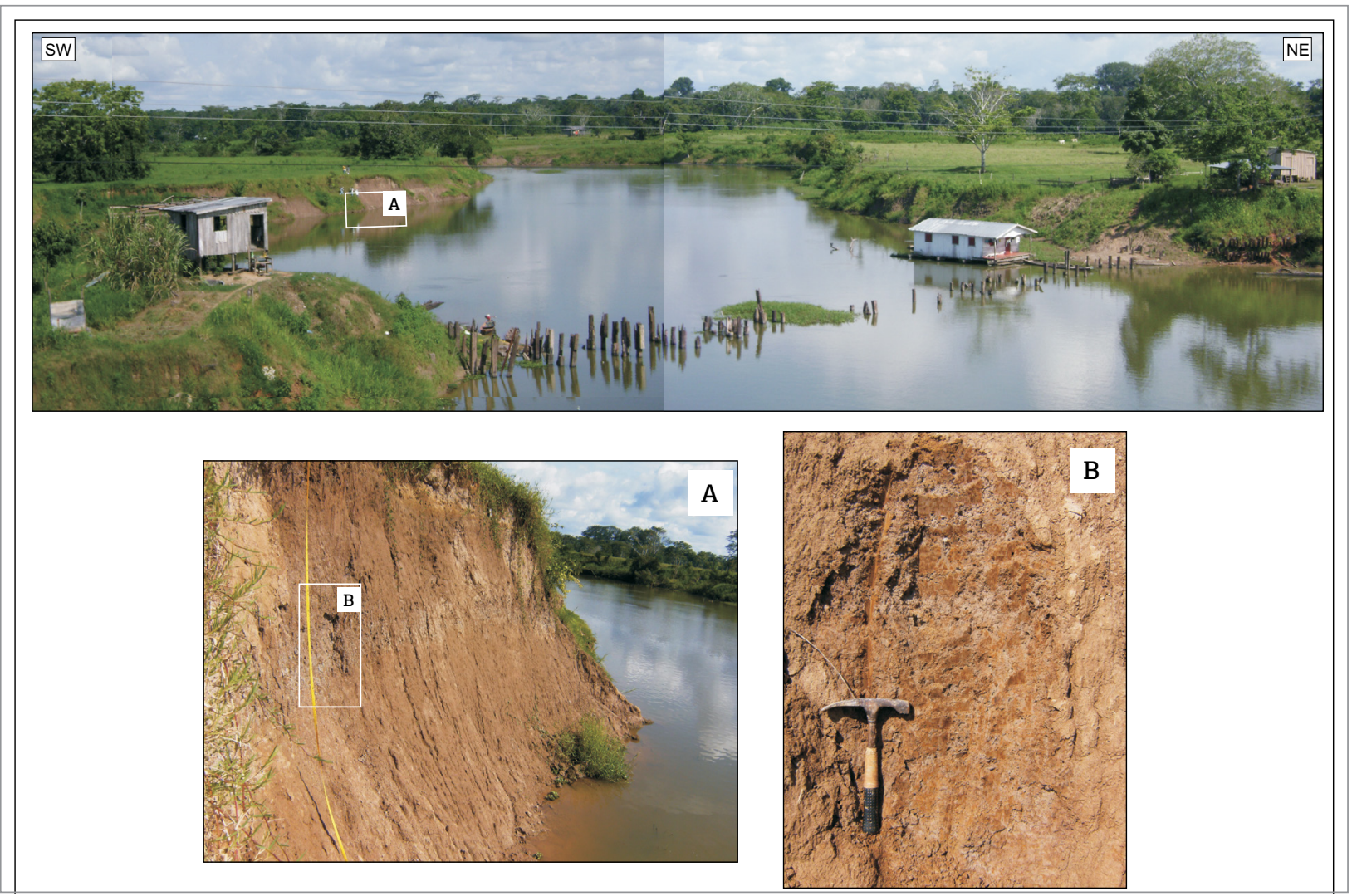

Figure 7. Typical relief of Intermediate Terrace surface, sectioned by a tributary river. A and B show details of the river margin composed by brown massive silt-clay sediments.

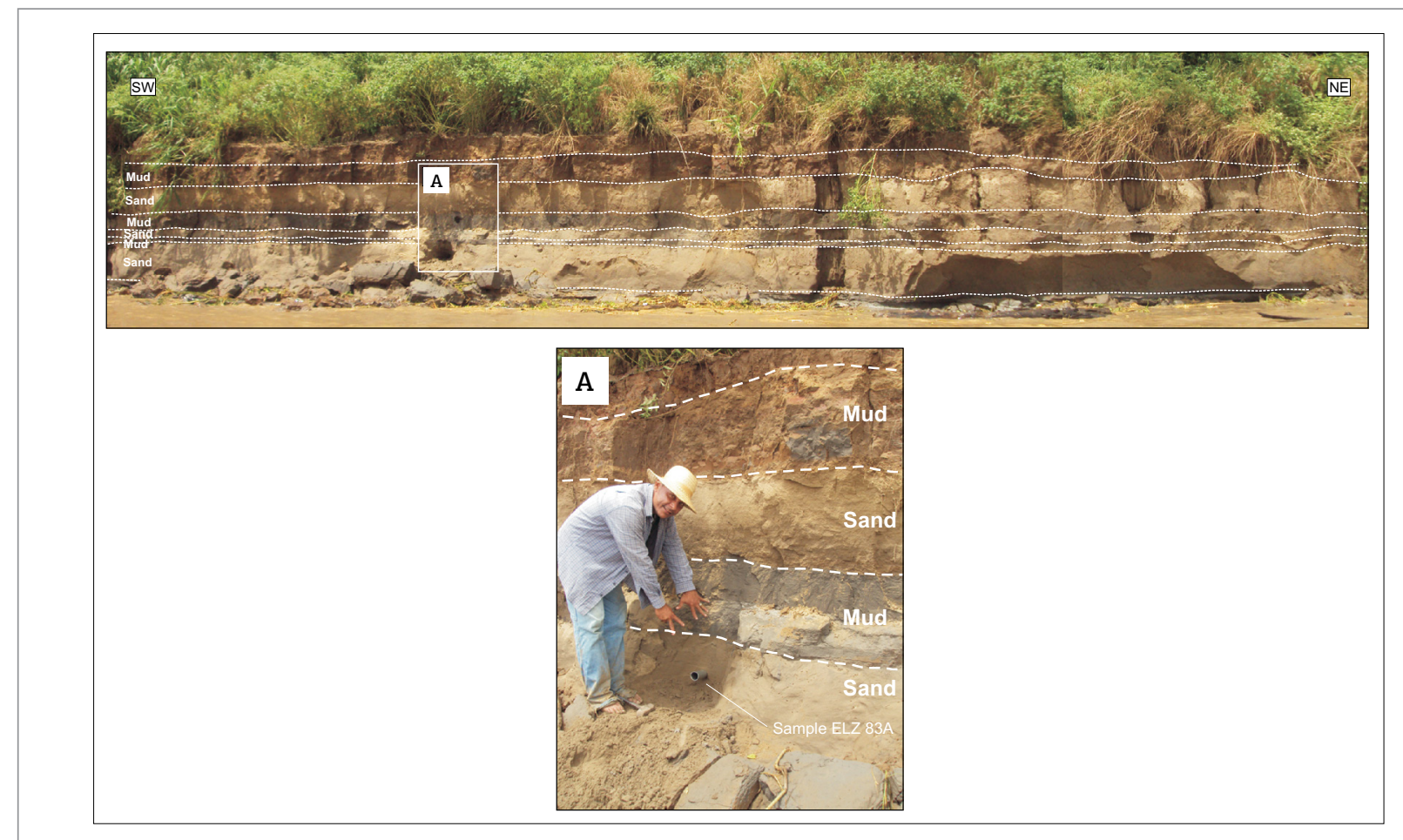

Figure 8. Lower Terrace outcrop on Solimões River right brink showing the front face of a point bar constituted by intercalations of mud (dark grey) and sand (light grey) metric layers. (A) Detail of layers forming the inclined heterolithic stratification, and the site of sampling to optically stimulated luminescence analysis. 
tectonic blocks basculation as one of the causes of progressive abandon of the Solimóes-Amazon system floodplain from South to North.

The OSL data found related to the lower terrace deposits suggest that the beginning of the sedimentation became the predominance of a meandering fluvial system at the end of Upper Pleistocene. However, given the environmental changes and subsidence action recorded in the Holocene, it is reasonable to assume that part of the development of this geomorphological unit occurred during a gradual transition period, from the meandering pattern to the current anabranching, which was probably concluded around 7,000 to 6,000 years ago, with the maximum regional base level caused by the sea level rise. Thereby, the point bar deposits younger than $7,300 \pm 2,000$ OSL ages are considered results from the secondary channels of an anabranching river, corroborating the fluvial dynamics proposal by Rozo et al. (2012).

\section{Evolution model of Quaternary fluvial terraces}

Subsidence phase on the basin floor (Rossetti et al. 2005, Soares 2007) enabled the initial deployment of the Solimões-Amazon fluvial system hundreds of kilometer southward from the current main channel (Fig. 10A). Attained OSL ages suggest the beginning of the UT sedimentation at 240,000 $\pm 16,000$ years ago, at the end of the Middle Pleistocene, extending until the Upper Pleistocene at 51,000 $\pm 5,000$ years ago (Fig. 10B).

Afterwards, the increasing displacement of the basin South brim (Soares 2007) associated with the regional base level drop caused by the sea level fall in the Late Pleistocene (Irion $\mathrm{et} \mathrm{al}$. 1997), afforded the northward fluvial system continuous lateral migration, thus developing the IT level between 30,900 \pm 8,000 and 19,100 \pm 6,300 years ago (Fig. 10C).

The northward meandering fluvial system progress was interrupted, and its sinuosity started to decrease when the main channel reached a resistant and elevated obstacle represented

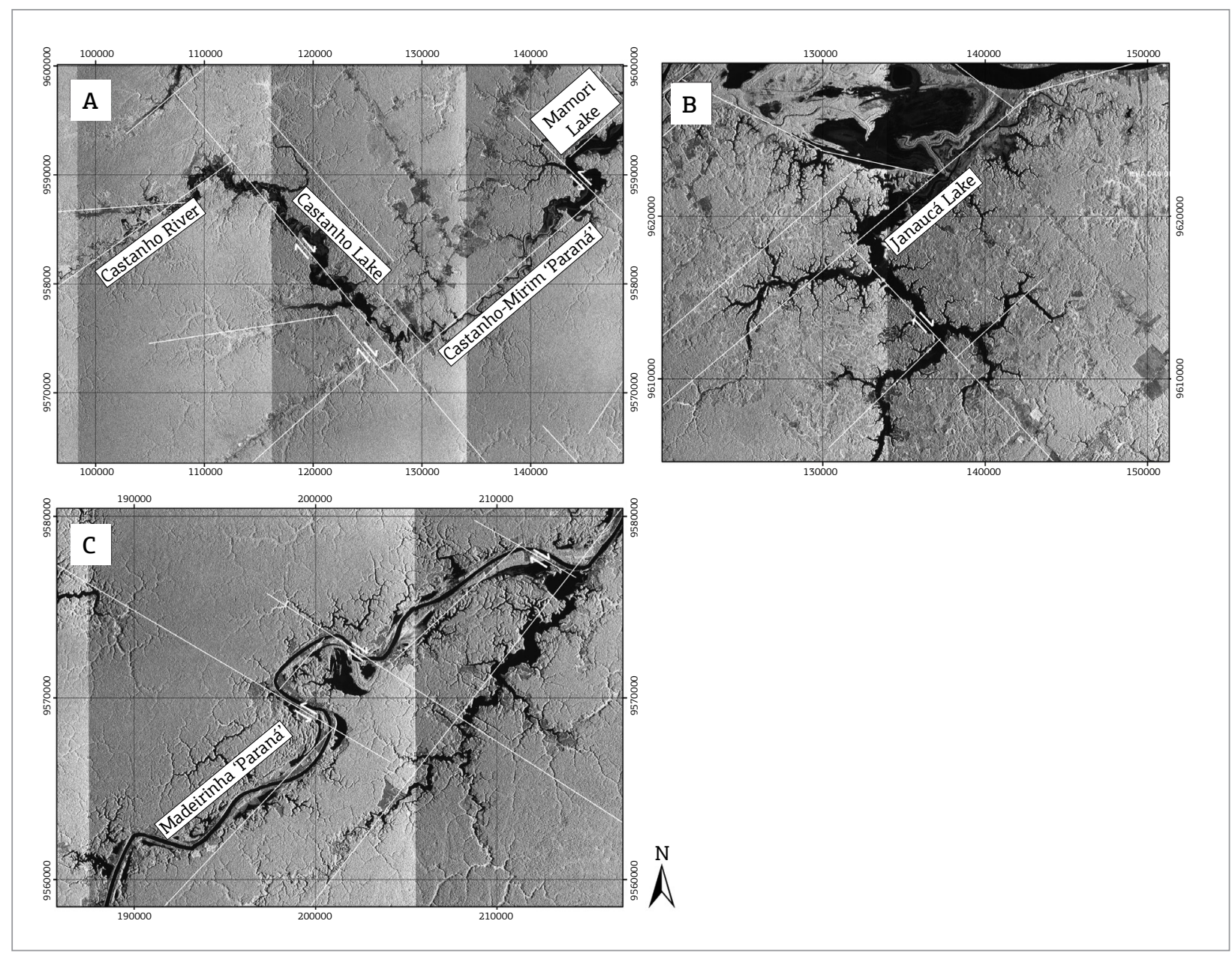

Figure 9. Fluvial capture features on Castanho River (A), Janauacá Lake (B), and Paraná Madeirinha (C). Sets of subrectangular pattern of drainages prevails on the study area afforded by NE and NW (orthogonal) lineaments trend. 


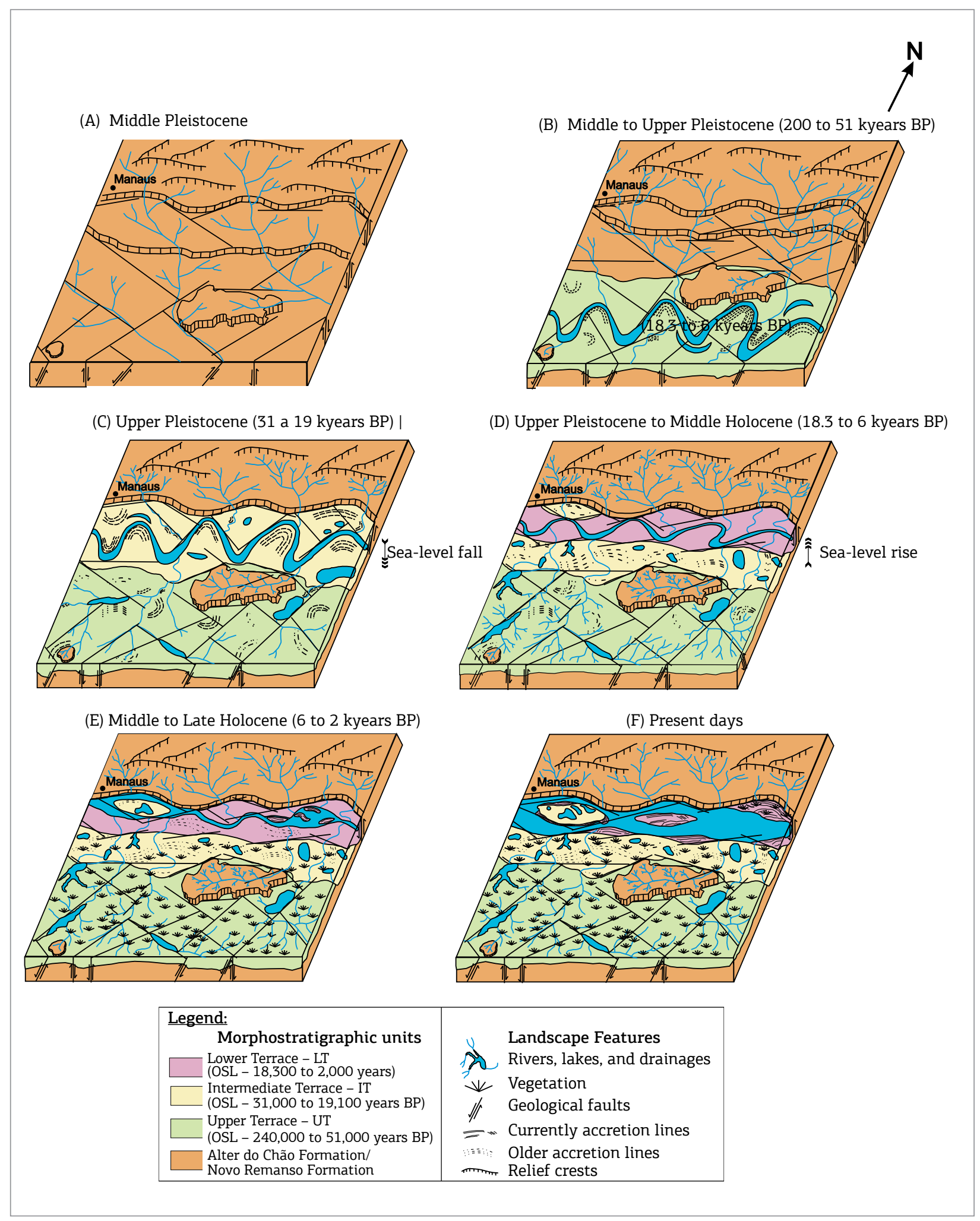

Figure 10. Landscape evolution model diagrams from the Pleistocene until the present days.

by cliffs of Alter do Chão and Novo Remanso Formations sited between Manacapuru and Itacoatiara regions, developing the LT between $18,300 \pm 4,400$ and 7,300 $\pm 2,000$ years ago (Fig. 10D). The point bars younger than 7,300 \pm
2,000 years were probably developed through the action of alluvial secondary channels system in a transitional fluvial pattern similar to an anabranching river, but holding some sinuosity inherited by the extinct meander river (Fig. 10E). 
In the last 2,000 years, the Solimóes-Amazon fluvial system, between the Negro and Madeira rivers tributaries, has showed a well stable anabranching pattern with low rates of channels migration (Mertes et al. 1996, Rozo et al. 2005; 2012, Passos et al. 2012). The consistency of the younger fluvial bars top is corroborated for ${ }^{14} \mathrm{C}$ ages up to $2,800 \mathrm{BP}$ attained by Sternberg (1960), dating Native American ceramics and Absy (1979) organic matter. Nowadays, the Solimóes-Amazon system truncates and reworks the IT and the LT deposits (Fig. 10F), favoring the development of unconsolidated sandy bars within the main channel and forming elongated islands.

\section{CONCLUSIONS}

The present study enabled the establishment of a relation between the morphostratigraphic sequence evolution and the reassembly of the Solimóes-Amazon river in the extent between Negro and Madeira tributaries activity in the last 240,000 years. OSL findings have showed the beginning of sedimentation in the Solimões-Amazon fluvial system floodplain from the Middle to Upper Pleistocene. They also evidenced a Northward main channel migration trend, leaving behind, for a hundred kilometers, three terraces levels mostly formed by different proportioned mud and sand intercalated layers, representing IHS pairs in old point bars. This fact suggests the prevailing of the meandering fluvial style throughout the Upper Pleistocene, corroborated by the kilometric paleochannel features truncating the fluvial terraces.

Since the Middle Holocene until nowadays, the gradual conversion from the meandering to the current anabranching system has been happening, due to the increase of the regional base level caused by the sea level rise registered from the Upper Pleistocene to the Middle Holocene. It is associated with the environmental changes in the past 7,000 to 6,000 years in Amazon that were driven by the increasing humidity rates and consequent development and expansion of the rain forest, therefore providing the stabilization of river banks and, ultimately, the tectonic features, represented by rhombograbens that enabled the Holocene sedimentation in the Solimôes-Amazon current river course.

\section{ACKNOWLEDGMENTS}

The financial support was provided by Fundação de Amparo à Pesquisa do Estado do Amazonas (FAPEAM) through the project: "Estudo Sedimentológico e Estratigráfico das Unidades Sedimentares Cretáceas-Cenozoicas aflorantes nas regióes do Careiro-Castanho e rio Manacapuru, Amazônia Central' (FAPEAM/MCT/CNPQ-INFRA n ${ }^{\circ}$ 012/2009). The authors also thank the CENSIPAM in Manaus for gently providing the satellites and radar images used in this study.

\section{REFERENCES}

Absy M.L. 1979. A palynological study of Holocene sediments in the Amazon Basin. PhD Thesis, University of Amsterdam, Amsterdam, 100 p.

Baker P.A., Seltzer G.O., Fritz S.C., Dunbar R.B., Grove M.J., Tapi P.M., Cros L.S., Rowe H.D., Broda J.P. 2001. The history of South America precipitation for the past 25,000 years. Science, 291(5504):640-643.

Behling H. 2011. Holocene environmental dynamics in coastal, eastern and central Amazonia and the role of the Atlantic sea-level change. Geographica Helvetica, 66(3):208-216.

Behling H., Bush M.B., Hooghiemstra H. 2010. Biotic development of Quaternary Amazonia: a palynological perspective. In: Hoorn C. \& Wesselingh F.P (eds.) Amazonia: landscape and species evolution. A look into the past. Oxford, Wiley-Blackwell Publishing Ltd., p. 335-345.

Blum M.D. \& Törnqvist T.E. 2000. Fluvial responses to climate and sealevel change: a review and look forward. Sedimentology, 47(1):2-48.

Costa J.B.S., Bemerguy R.L., Hasui Y., Borges M.S., Ferreira Junior C.R.P., Bezerra P.E.L., Costa M.L., Fernandes J.M.G. 1996. Neotectônica da região amazônica: aspectos tectônicos, geomorfológicos e deposicionais. Geonomos, 4(2):23-44.

Dantas M.E. \& Maia M.A.M. 2010. Compartimentação geomorfológica. In: Maia M.A.M \& Marmos J.L. (org.) Geodiversidade do estado do Amazonas. Manaus, Serviço Geológico do Brasil-CPRM, p. 27-44.
Dino R., Soares E.A., Riccomini C., Antonioli L., Nogueira A.C.R. 2006. Caracterização palinoestratigráfica de depósitos miocênicos da bacia do Amazonas, região de Manacapuru, AM. In: VII Simpósio do Cretácio do Brasil Cretáceo, I Simpósio do Terciário do Brasil, Serra Negra, Anais, p. 43.

Dino R., Soares E.A., Antonioli L., Riccomini C., Nogueira A.C. 2012. Palynostratigraphy and sedimentary facies of middle miocene fluvial deposits of the Amazon Basin, Brazil. Journal of South American Earth Sciences, 34:61-80.

Fernandes Filho L.A. 1996. Geologia, Mineralogia e Geoquímica dos Lateritos de Manaus-Amazon. MS Dissertation, Instituto de Geociências, Universidade Federal do Pará, Belém, 96 p.

Fiore M., Soares E.A.A., Mittani J.C.R., Yee M., Tatumi S.H. 2014. OSL dating of sediments from Negro and Solimões rivers - Amazon, Brazil. Radiation Physics and Chemistry, 95:113-115.

Franzinelli E. \& Igreja H.L.S. 1990. Utilização do sensoriamento remoto na investigação da área do baixo Rio Negro e grande Manaus. In: VI Simpósio Brasileiro de Sensoriamento Remoto, Manaus, Anais, v. 3, p. 641-648.

Franzinelli E. \& Igreja H.L.S. 2011. Ponta das Lajes e o Encontro das Águas, AM - A Formação Alter do Chão como moldura geológica do espetacular Encontro das Águas Manauara In: Winge M., Schobbenhaus C., Souza C.R.G., Fernandes A.C.S., Berbert-Born M., 
Sallun Filho W., Queiroz E.T. (eds.) Sítios Geológicos e Paleontológicos do Brasil. Brasília, Serviço Geológico do Brasil-CPRM, 3, 332 p. Available at: <http://sigep.cprm.gov.br/sitio054/sitio054.pdf>. Accessed in Jan. 2016.

Gonçalves Junior E.S., Soares E.A.A., Tatumi S.H. 2014. Terraços fluviais Quaternários do sistema Solimões-Amazon ao sul de Manaus. In: $47^{\circ}$ Congresso Brasileiro de Geologia, Salvador, Anais, CD-ROM.

Igreja H.L.S. 1998. Aspectos do modelo neotectônico na Placa SulAmericana na Província Estrutural Amazônica, Brasil. Thesis, Universidade Federal do Amazonas, Manaus, 155 p.

Igreja H.L.S. 2012. A neotectônica e as mudanças hidrogeológicas do sistema fluvial Solimões-Amazon: "Encontro das águas de Manaus - EAM" - Amazon, Brasil. Revista Geonorte, Edição Especial, 2(4):20-33.

Igreja H.L.S., Franzinelli E., Repolho T. 1999. Neotectonic influence on fluvial capture in the Amazon Basin, state of Amazon, Brazil. In: GLOCOPH '98 conference, Kumagaya, Science Reports of Tohoku University, v. 49(2), p. 197-206.

Irion G., Junk W.J., Nunes de Mello J.A.S. 1997. The large central Amazonian rivers floodplain near Manaus: geological, climatological, hydrological and geomorphological aspects. In: Junk W.J. (eds.) The central Amazon floodplains: ecology of a pulsing system. Berlin, Spring Verlag, p. 23-46.

Kistler P. 1954. Historical resume of the Amazon Basin. PETROBRAS/ RENOR, Belém, Relatório Interno.

Latrubesse E.M. \& Franzinelli E. 1993. Reconstrução das condições hidrogeológicas do passado. Ciências Hoje, 16(93):40-43.

Latrubesse E.M. \& Franzinelli E. 2002. The Holocene alluvial plain of the middle Amazon River, Brazil. Geomorphology, 44(3):241-257.

Latrubesse E.M. 2008. Patterns of anabranching channels: The ultimate end-member adjustment of mega rivers. Geomorphology, 101:130-145.

Mertes L.A.K, Dunne T., Martinelli L.A. 1996. Channel-floodplain geomorphology along the Solimões-Amazon River, Brazil. Geological Society of American Bulletin, 108(9):1089-1107.

Mörner N.A. 2005. Changing sea-levels. In: Schwarts L.M. (eds.) Encyclopedia of coastal science. Dordretch, Spring, p. 229-233.

Murray A.S. 1981. Environmental radioactivity studies relevant to thermoluminescence dating. PhD Thesis, Oxford University, Oxford, 391 p.

Murray A.S \& Wintley A.G. 2003. The single aliquot regenerative dose protocol: potential for improvements in reliability. Radiation Measurements, 37:377-381.

Nanson G.C. \& Knighton A.D. 1996. Anabranching rivers: their cause, character and classification. Earth Surface Process and Landforms, 21:217-239.

Passos M.S., Soares E.A.A., Salazar C.A. 2012. Análise bitemporal do Rio Solimões no trecho entre Manacapuru e Manaus (Amazônia Central) por meio de imagens Landsat-5/TM. In: $43^{\circ}$ Congresso Brasileiro de Geologia, Santos, Anais, CD-ROM.

Prescott J.R., Clay R.W. 2000. Cosmic ray dose rates for luminescence and ESR dating: measured with a scintillation counter. Ancient TL, 18:11-14.

Riccomini C., Gianinni P.C.F., Mancini F. 2000. Rios e processos aluviais. In: Teixeira W., Toledo M.C.M., Fairchild T.R., Taioli F. (eds.) 2000. Decifrando a Terra. São Paulo, Oficina de Textos, 568 p.

Riker S.R.L., Reis N.J., D’Antona R.J.G., Brito I.A. 2008. Projeto materiais de construção no domínio médio Amazona. In: Informe de Recursos Minerais, Série Rochas e Minerais Industriais n 3. Manaus, Serviço Geológico do Brasil-CPRM, 168 p., CD-ROM.
Rossetti D.F., Toledo P.M., Góes A.M. 2005. New geological framework for Western Amazonia (Brazil) and implications for biogeography and evolution. Quaternary Research, 63(1):78-89.

Rozo J.M.G. 2004. Evolução Holocênica do Rio Amazonas entre a Ilha do Careiro e a foz do Rio Madeira. Msc Thesis, Departamento de Geociências, Universidade Federal do Amazonas, Manaus, 93 p.

Rozo J.M.G., Nogueira A.C.R., Carvalho A.S. 2005. Análise multitemporal do sistema fluvial do Amazonas entre a Ilha do Careiro e a foz do Rio Madeira. In: XII Simpósio Brasileiro de Sensoriamento Remoto, Goiânia, Anais, p.1875-1882.

Rozo J.M.G., Nogueira A.C.R., Truckenbrodt W. 2012. The anastomosing pattern and the extensively distributed scroll bars in the middle Amazon River. Earth Surface Processes and Landforms, 37(14):1471-1488.

Silva C.L., Morales N., Crósta A.P., Costa S.S., Jiménez-Rueda J.R. 2007. Analysis of tectonic-controlled fluvial morphology and sedimentar processes of the Western Amazon Basin: an approach using satellite images and digital elevation model. Anais da Academia Brasileira de Ciências, 79(4):693-711.

Smith D.G. \& Putnam P.E. 1980. Anastomosed fluvial deposits: modern and ancient examples from Alberta, Canada. Canadian Journal of Earth Sciences, 17(10):1396-1406.

Soares E.A.A. 2007. Depósitos pleistocenos da região de confluência dos rios Negro e Solimões, Amazonas. PhD Thesis, Instituto de Geociências, Universidade de São Paulo, São Paulo, 205 p.

Soares E.A.A., Tatumi S.H., Riccomini C. 2010. OSL age determinations of Pleistocene fluvial deposits in central Amazonia. Anais da Academia Brasileira de Ciências, 82(3):14-19.

Sternberg H. 1960. Radiocarbon dating as applied to a problem of Amazonian morphology. In: XVIII Congress International de Géographic, Anais, v. 2, p. 399-424.

Tatumi H.S., Silva L.L., Pires E.L., Rossetti D.F., Góes A.M., Munita C.S. 2008. Datação de sedimentos pós-barreiras no norte do Brasil: implicações paleogeográficas. Revista Brasileira de Geociências, 38(3):514-524

Teixeira S.G. \& Soares E.A.A. 2011. Uso de imagens multi-sensores na identificação de paleocanais na planície aluvial do Rio Solimões, Amazônia Ocidental. In: XIII Congresso da Associação Brasileira de Estudos do Quaternário - ABEQUA. Búzios, Anais, CD-ROM.

Thomas R.G., Smith D.G., Wood J.M., Visser J., Calverley-Range E.A., Koster E.H. 1987. Inclined Heterolithic Stratification - terminology, description, Interpretation and significance. Sedimentary Geology, 53(1-2):123-179.

Vieira P.C. 1981. Variações no nível marinho: Alterações eustáticas no Quaternário. Revista Instituto de Geociências, 2(1):39-58.

Walker M.J.C., Berkelhammer M., Björck S., Cwynar L.C., Fisher D.A., Long A.J., Lowe J.J., Newnham R.M., Rasmussen S.O., Weiss H. 2012. Formal subdivision of the Holocene Series/Epoch: a Discussion Paper by a Working Group of INTIMATE (Integration of ice-core, marine and terrestrial records) and the Subcommission on Quaternary Stratigraphy (International Commission on Stratigraphy). Journal of Quaternary Science, 27(7):649-659.

Wright V.P., Marriott S.B. 1993. The sequence stratigraphy of fluvial depositional systems: The role of floodplain sediments storage. Sedimentary Geology, 86:203-210.

Zhang Z., Sun K., Yin J. 1997. Sedimentology and sequence stratigraphy of the Shanxi Formation (Lower Permian) in the northwestern Ordos Basin, China: an alternative sequence model for fluvial strata. Sedimentary Geology, 112:123-126.

Available at www.sbgeo.org.br 